\title{
Candomblé rituals and food practices in Italy and Brazil: an ethnographic comparison
}

Práticas alimentares e ritualísticas no Candomblé: uma comparação etnográfica entre Itália e Brasil

\section{Giovanna Capponi}

França. Musée du Quai Branly. Graduação em Scienze antropologiche pela Università di Bologna (2009), mestrado em Antropologia e Etnologia Culturale pela Università di Bologna (2013), mestrado em Migration and Diaspora Studies pela School of Oriental and African Studies (2011) e doutorado em Social Anthropology pela University of Roehampton (2018). Atualmente é pesquisadora de Pós-Doutorado no Musée du Quai Branly. ID ORCID: https://orcid.org/0000-0002-7196-3627. E-mail: giovanna.capponi@gmail.com.

\section{Abstract}

This paper focuses on the relationship between food practices, preparation of Candomble ritual offerings and performance of rituals in a transnational case study. My interest here is to consider two ethnographic accounts of Candomblé rituals in Italy and Brazil. I will analyze how Italian practitioners perceive different aspects of the preparation of ritual offerings and what values are at stake in the cooking and consumption of food and food offerings. I will show how memory and the senses are essential to build a new idea of familiarity and to learn new skills within the ritual practice.

Keywords: Candomblé, Transnationalization, Afro-Brazilian Religions, Food practices, Offerings, Sacrifice.

\section{Resumo}

Este artigo analisa a relação entre as práticas alimentares, a preparação de oferendas rituais do Candomblé e a realização de rituais em um estudo de caso transnacional. É meu interesse aqui levar em conta dois relatos etnográficos de rituais de Candomblé na Itália e no Brasil. Vou explicar como os praticantes 
italianos percebem diferentes aspectos da preparação das oferendas rituais e que valores estão em jogo na cozinha e no consumo de alimentos e oferendas. Aliás, vou mostrar como a memória e a dimensão sensorial são essenciais para construir uma nova ideia de familiaridade e para aprender as técnicas de preparação dentro da prática ritual.

Palavras-chave: Candomblé, Transnacionalização, Religiões Afro-brasileiras, Alimentação, Oferendas, Sacrifício.

Fieldwork Notes:

"É pronto! (It's ready!)". Pai Mauro calls his filhos de santo to have lunch in

the kitchen. He likes to cook, and he carefully plans the meals during events and rituals in his Candomble house, when followers and sympathizers come to stay for a few days and to participate in the ceremonies. As an Italian food lover, over the years Pai Mauro prepared a menu that stays almost the same, especially over the celebrations for Oxalá, a deity connected to purity and silence, who forbids the use of dark and red food items and therefore, prohibits the use of the beloved Italian tomato sauce in certain occasions. The menu includes tuna and rice salad, gnocchi with gorgonzola sauce, roasted chicken with potatoes, pasta carbonara with zucchini, and some Asian dishes, like Chinese fried rice and Thai curry. At the same time, a piece of paper with a list of the sacred offerings to be prepared is hanged on the fridge door. It includes acaça (white maize porridge wrapped in banana leaves), canjica (boiled white maize), farofa (manioc flour) and yam puree, among other things.

\section{INTRODUCTION}

This paper aims to compare food practices and sacrificial rituals in two different Candomblé houses, in the state of São Paulo, Brazil, and Northern Italy. Candomblé Ketu is part of a cluster of Afro-Brazilian religions based on

Candomblé practitioners and members of a Candomblé community. 
the cult of the orixás, anthropomorphic deities and energies of nature who originated in Yorubaland, a vast area that historically has been shared between Nigeria and Benin (LOPES, 2004). One of the most compelling characteristics of Candomble is the variety and complexity of rituals, including food preparation and food offerings. As shown in other works, in Candomblé terreiros (temples) everything and everyone (human and non-human entities) "eat" (JOHNSON, 2002, p. 36), and feeding the orixás with offerings and sacrificial blood is an essential part of the religious practice.

I collected most of the data during a multi-sited fieldwork between Italy and Brazil, between 2014 and 2016. The Ilé Axé Alaketu Airá, located in Arborio (Vercelli, Northern Italy) was founded in the late 1990s by Pai Mauro, an Italian pai de santo ${ }^{2}$ who underwent his initiation in São Paulo, Brazil. I already recounted Pai Mauro's story in detail elsewhere (CAPPONI, 2018, p. 166-168), but here it is important to mention that the Italian Candomblé priest maintains as its reference the terreiro of his own pai de santo, Pai Odé, located in Juquitiba, in the state of São Paulo. In an attempt to understand the network of relations and references of the Italian Candomblé house, I had the opportunity to interact with other related temples in Brazil, following the genealogy of Pai Mauro up to the Casa de Oxumaré, one of the most traditional temples of Salvador. However, I also had contact with other unrelated religious temples of both Candomblé and Umbanda, which helped in understanding the diversity and multiplicity of the ritual practice in the Afro-religious contexts. With the help of these suggestions, my interest in this article is to compare and analyze how different aspects of the preparation of ritual offerings (chicken sacrifice, cooking and consumption) are perceived by Italian practitioners, and what values are at stake in these practices.

\footnotetext{
Religious authority who has the right to establish a temple and create a religious community. The denomination of pai (father) and mãe (mother) denotes a family-like structure that is present in Afro-diasporic religions. Candomblé practitioners maintain, after the initiation, ties of hierarchy and obligations with their initiator and their religious family, called família de santo.
} 


\section{RITUALS AS RECIPES: A TRANSNATIONAL CASE}

Various aspects of the transnationality of Afro-Brazilian religions have been examined by different authors in the last two decades. Comparative case studies in France, Portugal, Italy and Germany have often considered different perceptions of health and healing (TEISENHOFFER, 2007), bodily performance (BAHIA; DANTAS, 2018) and the interaction with the hosting state in terms of regulations (SARAIVA, 2013), among other topics. Many authors investigated the historical reasons and migratory fluxes that gave rise to the expansion of Afro-Brazilian religions, like in the case of Portugal (GUILLOT, 2010), but also the ways in which Afro-Brazilian cosmologies resonated with local beliefs and practices (BASTOS, 2001). Indeed, it has been observed that the orixás enter the transnational imaginary through Brazilian music, by being associated with Catholic saints or through local magico-religious practices or new age beliefs (GOLFETTO, 2018).

However, transnational studies so far did not pay enough attention to the material dimension of Afro-Brazilian religions and the multiple adaptations that are necessary for their process of expansion and transnationalization. Few exceptions include works that take into account ritual objects that circulate as commodities in the Afro-religious market across nations (herbal baths, statues, divination objects, amulets etc.), and how these objects are transformed and used within the transnational contexts (BAHIA, 2018, p. 160; GUILLOT; HUET, 2012, p. 24).

An essential part of this materiality is composed of food items, ritual and non-ritual practices of food preparation, and the interaction with sacrificial animals from slaughter to consumption.

Food brings about notions of identity, embodiment and enskillment (SUTTON, 2013) that must be considered in migratory and transnational contexts. Food items are also acquired, imported and exchanged as commodities, giving place to a cross-border market and endorsing dynamics of adaptations and transformation (CAPPONI, 2018, p. 171-174). In this framework, however, sacrificial animals (one of the main components of ritual and non-ritual food practices in Candomblé) cannot be solely considered as 
commodities or ingredients. The interaction with live animals in rituals also includes a set of emotional and symbolic aspects, notions of animal agency, participation, and identification with the sacrificial victim (FIRTH, 1963). By considering the complexity of materiality and food practices in the study of Afro-Brazilian religions, it is my interest here to analyze how different phases of the preparation of ritual offerings are perceived by Italian practitioners and what values are at stake in the cooking of offerings.

In the typical tension between tradition and innovation, studies of both food and ritual practices always pointed at the creative ways in which these were adapted to different contexts, needs and times. Lewis (1980) explains how rituals do not follow encrypted codifications but are freely interpreted in an experiential process. Ritual practices imply not only a set of rules imposed by tradition but an expertise and specialist knowledge in the making and manipulating of ingredients, objects, sounds and energies. Thus, I use the metaphor of rituals as recipes: to make a specific dish, certain ingredients are required. While some of these items can be replaced or substituted, others are fundamental to maintain its identity. The same applies to its execution and aesthetic. However, the ability to know (or sense) which are the essential parts of a ritual and which can instead be replaced, omitted or innovated, can be acquired only by absorbing the cultural values associated to those actions and by intimately understanding the meaning and purpose of the ritual. Beyond symbols, rules and traditions, rituals are characterized by sensorial experience and combine material culture, cultural knowledge, social values and group identity, that can be relate to the notion of sensibility coined by Kathryn Linn Geurts (2002, p. 17): "as a term that unites individual experience with perception, thought, cultural meaning, and social interaction".

In the ritual preparation of food offerings, Candomblé practitioners must consider the tastes of non-human invisible entities. Each orixá has a set of favorite recipes that are prepared and offered in the or $\hat{o}^{3}$. For example, Oxossi ${ }^{4}$ likes to eat roasted black-eyed peas, but also a dish called axoxo, boiled yellow corn decorated

\footnotetext{
Ceremony in which the orixás are fed through food offerings and sacrificial blood.

4 The orixá of hunting and prosperity.
} 
with coconut. Similarly, the most popular dishes to be offered to Oxumaré ${ }^{5}$ are a plantain cut lengthwise and fried in palm oil, and mashed sweet potatoes with honey. Each time an orixá is celebrated and fed, they will receive one dish or two, together with some animals and birds. Some of these dishes were likely part of the daily diet of West African descendants, who were offering their own meals to the deities. The Museu Afro Brasil of São Paulo presents a list of dishes that were popular among enslaved Afro-descendants - like acarajé, caruru, xinxin, abará, ipete - names often heard in the kitchens of Candomblé terreiros and that constitute some of the sacred food offerings. Some of these dishes continue to be part of the daily diets and regional cuisine of Northeastern Brazil, where Afro-Brazilian culture maintains strong roots. Pai Odé makes an interesting declaration on this aspect of permeability between daily food practices and ritual offerings: "What is offered to the orixá? Initially, people offered what they had [...] if in ancient times, the spaghetti had existed and had been offered, there could be today an orixá who likes spaghetti, right?"'. This quote shows how in Candomblé the tastes of both humans and deities are not fixed, but evolve and are constructed alongside culinary traditions, availability and exchanges of items.

Some of the dishes that comprise traditional Candomble food offerings are so popular that can even be found in specific cookbooks. However, some others are less known by the general public and jealously kept secret by religious authorities. Babá Egbé Leandro, one of the referees of the traditional Casa de Oxumaré in Salvador, argues that those popular recipes have been offered too many times to the orixás and consequently have lost their power. Conversely, some of the "secret" and less common recipes are used by experienced sacred fathers and mothers ${ }^{7}$ whenever they need to trigger an immediate reaction from the deities. Despite the ritual prescriptions, the preparation of an offering always requires some amount of personal

5 The orixá of the rainbow and transformation represented as a rainbow snake.

6 Pai Odé: O que é oferecido pro orixá? O povo no início oferecia pro orixá aquilo que ele tinha. [...] não é dito que se em tempo remoto já tivesse o espaguetti, que eles ofereciam e agora não teria um orixá que gosta de espaguetti, pode ser?

7 The terms "pai de santo" and "mãe de santo" have been often translated as "mother/father of the saint" in most anglophone literature. However, I propose to use the adaptation "sacred father/mother", to maintain the conjunction of sacred and sanctified ties that these relations imply (CAPPONI, 2018, p. 167). 
sensitivity and creativity. As a sacred mother told me, "sometimes I do things the usual way, but then I feel that something is wrong and I know that I must add something else, or that this ingredient cannot be used this time". By playing with the axé - sacred energy - contained in each combination of ingredients, Candomblé practitioners learn to mediate between the tastes of the orixás and the needs of humans.

This example of how the tastes of the invisible world are taken into consideration was brought back into my fieldwork by Tata Kajalacy, a Candomblé priest of the northern coastline of the state of São Paulo. During a divination session, he warned me that an ancestor of mine was hindering my life plans. To convince him to leave me alone, I needed to make an offering. However, Tata Kajalacy was not sure about what kind of offering I should prepare. After pondering different options, he said, "Well, you are Italian... make pasta for him!"”. It seemed likely to the sacred father that my troublesome ancestor shared my same origins; therefore, it was reasonable to suggest that a "pasta offering" would have tamed him. Tata Kajalacy also admits that given the high percentage of Italian and French descendants in São Paulo (being himself of Jewish French heritage) he often uses bread for healing rituals involving ancestors. These insights show not only the general plasticity and adaptability of rituals but also the transnational and transcultural aspect of commensality between humans and invisible entities. Humans, orixás, and ancestors are fed considering their tastes and origins. However, it is also true that visible and invisible social actors learn to familiarize with and accept different foods, dishes and forms of preparation in the ritual framework. In the following sections, I will explain how, in the Italian and the Brazilian case studies, Candomblé offerings and ritual practices are constructed through different memories, social structures and tastes.

Tata Kajalacy: Bom, você é italiana... faça macarrão para ele! 


\section{COMPARING ETHNOGRAPHIC ACCOUNTS BETWEEN ITALY AND BRAZIL}

I will compare two ethnographic accounts of two similar ritual ceremonies I had the opportunity to observe. The rituals, dedicated to Yemanjá and Oxum, feminine deities of the ocean and the river, took place at Pai Mauro's house in Arborio (Northern Italy) in June 2015, and at Pai Odés Candomblé house in Juquitiba (São Paulo, Brazil) in December 2015. Arborio is a small village in a rural area surrounded by rice paddies, $70 \mathrm{~km}$ from Milan; while Pai Odés terreiro is situated in a remote area between Juquitiba and São Lourenço da Serra, $70 \mathrm{~km}$ from the city of São Paulo and is surrounded by a patch of Atlantic Forest. These two accounts will shed light on the differences between the ecological and social context in the Brazilian and the Italian case, focusing on food preparation and sacrificial rituals. These ethnographic accounts will be complemented by additional data and explanations; and will be divided into three parts. First, I will talk about the adaptations implemented in the Italian socio-cultural environment. Second, the memories and cultural references that contribute to building a new familiarity with the Afro-Brazilian food practices. Third, I will explore consumption choices both at an individual level (vegetarianism) and collectively (food served in public ceremonies).

\section{TIME AND PLACE: ADAPTING RITUAL TO AN ITALIAN SOCIAL ENVIRONMENT}

In the Italian Candomblé house, ceremonies are usually attended by ten to twenty-five people ${ }^{10}$. In the occasion here described, followers gathered not only to perform the annual rituals and sacrifices for the orixás Oxum and Yemanjá but also to help with the obrigação (literally "obligation", rite of passage) of two sacred

\footnotetext{
Some details will be omitted to respect the secrecy of the ritual practice.

${ }^{10}$ The Candomblé house of Arborio counted some 50 initiates from the times of its foundation, but those who regularly attended the ceremonies at the time of my research were around 20 people, of which roughly one third were Brazilians, and the rest almost all Italians.
} 
daughters. Carla ${ }^{11}$ de Oxum ${ }^{12}$, an Italian woman in her early fifties, going through a rite of passage marking her first year of initiation, while Marica de Yemanjá, in her early forties, is celebrating her three years within the religion. Both are originally from Piedmont: Marica lives in a small town a few kilometers from Arborio, while Carla needs to travel for a couple of hours by car to reach the terreiro from her village. Marica started attending the Candomblé house through her friends Sara and Tatiane (Pai Mauro's stepdaughter), who both underwent the initiation almost five years ago; Carla decided to join the religious community after being introduced by her friend Guido, an Italian devotee who lives in the same area. They arrived at the terreiro on a Thursday and get ready to start the rituals. Carla talks about how her life changed since the day of the initiation: she found courage to ask her husband for a divorce, and started a new business with her sister. However, she keeps her religious affiliation secret, "If the people in my village knew what I do, they would burn me at the stake". Similarly, Marica does not share the fact she is initiated with her family, as "they would not understand". Being the ones undergoing the ritual, they are not permitted to help with the preparations, which are performed by the sacred mother (Pai Mauro's wife), a couple of initiates and $\mathrm{me}^{13}$. The rest of the devotees arrived on Friday night when Carla and Marica started their seclusion period. Ritual isolation is a typical feature of every rite of passage. In their case, they must remain in the roncó, room dedicated to this kind of ritual isolation, until Sunday. In the Italian Candomblé house, a yawo ${ }^{14}$ completes the initiation in seven days. In this process, the novice's head is shaved, and sacrifices and offerings are performed to create a lifelong bond with the orixá. Afterwards, the novice is meant to keep three weeks of preceito, a transition period in which they must abstain from sex, alcohol and certain foods, while also following precise ritual prescriptions like dressing in white clothes, keeping their head covered, eating without cutlery, etc. In most Brazilian terreiros the seclusion period is typically twenty-one days, followed by three months of preceito.

\footnotetext{
11 Names have been changed to protect the privacy of my interlocutors.

12 In Candomblé, each follower is "son" or "daughter" of a different deity.

${ }_{13}$ During my research I was attending the Candomblé house of Arborio as an abian, a uninitiated who is considered part of the community, in a preparatory state.

14 Novice, initiated person with a lower position in the hierarchy.
} 
"Time" is an overly debated topic in Candomblé, and the number of days needed to perform rituals has been subjected to changes and adaptations over the decades. Some oral sources argue that originally the period of seclusion lasted for months and some Candomble houses still extend the time of preceito to a whole year. While many religious authorities defend that it is impossible to "make" an authentic yawó in less than three weeks, many others (like Pai Odé) argue that shrinking the ritual period is necessary to the maintenance (or even "survival") of Candomblé. In a contemporary world in which the notions of "work" and "productivity" are central social values, few people can afford to be absent from their jobs and families for an extended period. Therefore, most sacred fathers and mothers are asked to compromise and abandon religious orthodoxy in favor of a more pragmatic approach. This process of adaptation started in the Brazilian context and spread unavoidably in the European and American diaspora of Afro-Brazilian religions. Clara Saraiva (2010, p. 281-282), in her ethnography of a Candomblé terreiro in Portugal, describes similar processes of adaptation, in which not only the period of initiation is shorter, but the sacred father also avoids shaving the head of his sacred sons and daughters. Arnaud Halloy (2004, p. 457), singles out problems in keeping time and ritual prescriptions in a Candomblé house active in Belgium between 1988 and 2000. The author lists the difficulties that the terreiro faced during its founding in the city of Carnières. Among those, he indicates problems of compatibility between the devotees' family commitments and the ritual prescriptions, especially when the novices' relatives were unaware of the specific interdictions that come with the religious affliation, as in the case of Carla and Marica. For a simple obligation like the one the two women are undergoing, Pai Mauro prescribes that the seclusion period can take place over a long weekend.

Conversely, at Pai Odés house, rituals often last for a couple of weeks in a row. In December 2015, the Celebration of Oxum and Yemanjá had been scheduled right after another celebration, and some forty people were present the whole time to undergo various rites of passage, initiations or to help and participate in the rituals. On this specific occasion, five sacred sons and daughters underwent their obrigações: Mãe Vanessa de Oxum (early 50) and her biological daughter Thais de Oxum (20) celebrated twenty-one years within the religion, 
Pai Tom de Oxossi (early 30) took his axé of fourteen years, Rafaella de Yawá (early 20) celebrated her seven years, and Lucas de Oxossi (mid-twenties) marked his three years since the initiation. One interesting feature is that, while Italian initiates often hide their religious affiliation from their relatives, Pai Odés sacred family in Brazil comprise many biological families (couples with children, grandmothers and nephews, etc.) who share the same religious background and experience. As such, the transmission of ritual knowledge happens on multiple levels, from religious authority to novices, and from familiar authority to younger members.

\section{CONSTRUCTING THE FAMILIAR: MEMORY AND FOODSCAPES IN THE RITUAL PRACTICE}

The first orixá to be fed in Candomblé rituals is typically Exú, the messenger god and powerful trickster of Afro-Brazilian cosmology. In the kitchen of the terreiro of Arborio, I helped the sacred mother in preparing the $e b o^{15}$ for Exú: raw manioc flour mixed with palm oil, water and honey, roasted and boiled black beans, black-eyed peas, white corn porridge wrapped in banana leaves, etc. Most of these ingredients are not easily acquired in Italy and were bought in African or Asian shops in Novara or Vercelli, two small cities near Arborio. Banana leaves are particularly expensive as they are imported from Thailand or Vietnam. The sacred mother burns them slightly on the stove, cuts them meticulously to avoid waste and then stores the leftovers in the freezer. Since these ingredients are not commonly used in the Italian cuisine, the act of learning to cook the offerings for Italian Candomblé practitioners means not only learning how to feed the orixás correctly but also to familiarize themselves with different ingredients and the Brazilian cuisine. Manioc, beans and tubers are common Brazilian staples, and some ritual preparations like the acarajé - oval balls made with black-eyed peas and deep-fried in palm oil - is a popular food across regions, classes and religious identity (REINHARDT, 2018, p. 83-84).

\footnotetext{
${ }_{15}$ Preparatory offering.
} 
In the early afternoon, Alessandro, a young man who runs a small farm at the end of the road, delivered two cockerels. Alessandro is from the province of Milan, but came to live in Piedmont to help his father manage his business. They breed and sell poultry, and they sell live birds and fresh eggs to the local inhabitants. Alessandro's farm is also a certified poultry slaughterhouse, but his only customer is a restaurant from a nearby village. As he admits, the Candomblé house represents a regular source of income for his business, especially since he became good friends with Pai Mauro. It is interesting to note how the relationship of confidence and respect with livestock sellers is a common feature of many Candomblé houses in Brazil. Pai Odé recounts how his trusted livestock seller, who is a member of an Evangelical church, provides healthy animals for the rituals in a very professional way. In this context, business logic and market relations help overcome religious-based conflicts.

Back to Arborio, the sacred mother proceeded to wash and prepare the birds one by one. Holding them by the wings with one hand and by the neck with the other, she washed their heads, wings, feet and tail under running water and places them back in a small cage. Then, Pai Mauro performed the ritual offerings and the sacrifice for Exú with the help of all the devotees. At the end of the ebó, I followed some yawós to the back garden where a large pot of water was previously put to boil on a camping stove. We took the cockerels and began to pluck them by soaking the feathers in warm water to make the process easier. Afterwards, certain parts needed to be cut and set aside: the head, the feet, the tail, the wings, a piece of the neck, the point of the sternum, the liver, the heart, the stomach and the testicles. The feet need to be peeled and so does the crest, while the stomach is cleaned of any residual food.

These parts were given to the sacred mother, who washed them carefully and cooked them with palm oil and onion. This preparation is called "making the $a x e$ " and consists of extracting and preparing all the parts of the bird regarded as containing a high percentage of life energy. As a sacred daughter explained to me on a different occasion, each part has a symbolic value related to the devotees' life: the head represents one's individuality, the feet propitiate one's journey, the tail has the purpose of expelling negativity, the internal organs are filled with 
blood and life, etc. This aspect not only emerges through symbolic interpretation but also in the practice of preparation. If a sacred daughter forgets to cut a piece of the neck, an elder initiate jokes: "Don't you want stability in your life?".

Similarly, when someone cuts only the small point of the wing bone instead of the whole joint, an elder says: "Are your hands attached to your shoulders? No, you have the whole arm!". The disposition of the different parts follows a specific logic. The shape of the bird is reconstructed on a plate: the head is placed at the top, the wings on the sides and the internal organs at the center, while the feet need to be placed upwards, "just like your feet are facing forwards". As these details suggest, similarities and correspondences between human and animal anatomy are central in the preparation of sacrificial offerings, and carry a strong metaphorical meaning. The overlapping of human and animal bodily and spiritual identities is present in various ethnographic sources both in ritual sacrifice (AWOLALU, 1973, p. 83) and hunting contexts (WILLERSLEV, 2004). While not engaging with the extensive literature on the sacrifice, I want to highlight how the relationship between humans and animals (as sacrificial victims or prays) always involves a degree of empathy, mimesis and identification. As explained by Vogel et al. (1993, p. 104-105) in their work on the initiation rituals of Candomblé, the sacrificial bird dies to be reborn as an initiate, while the novice dies to be reborn as a guineafowl.

Saturday morning Pai Mauro gave us a list of food offerings to be prepared for the orixás Yemanjá and Oxum, which included, among other things, the acaçá, the already mentioned white corn porridge wrapped in banana leaves, the eboyá, white corn cooked and stir-fried with oil and onion (a typical dish offered to Yemanjá), and the omolocum, black-eyed peas cooked and stir-fried with palm oil, onion, dried shrimps and boiled eggs (one of Oxum's favorite food). At about 11 a.m. Alessandro delivered the animals needed for the big sacrificial ceremony performed in the afternoon. Devotees sometimes bring jewelry or shells to adorn orixás altar and complement the typical food offerings with cakes, pastries and sweets. The use of food offerings more palatable to the devotees than the prescribed recipes previously mentioned is now considered a traditional Candomblé practice. Adding iced cakes, meringues, and butter biscuits to the food offering table not only represents a devotional practice but 
responds to an aesthetic need. Historically associated with bloody sacrifice, primitive sorcery and low social classes, Candomble attempted to subvert this stereotypical image by incorporating baroque and rich elements like finely laced ribbons, inlaid garments and golden decorations. This process also affected the look and quality of the food offerings, that are carefully arranged in elegant and expensive porcelain, clay or wooden plates dedicated to each orixá, and are often complemented with a tray of sweets or a pudding (ARAÚJO, 2020).

Danilo, an Italian ogã $n^{16}$ and sacred son of Pai Odé, arrived in the morning to help with the ritual. Finally, Pai Mauro called the start of the orô. The cages with the birds were placed in the corridor, facing the orixás' rooms. All the participants, almost ten people in total, kneeled on the straw mats while the sacred mother, the sacred father and the ogãn leaded the ritual. When the blood was poured on top of the igbás, some devotees entered trance. Some suddenly raised their heads with closed eyes, wobbling their shoulders and even emitting their specific ilá, a sound that orixás make through the voices of their devotees. As can be observed, the orixás immediately respond to the sacrificial offerings and show their presence through trance possession. The renewal of the energy installed in the igbás corresponds to the restoration of the sacred sons and daughters' personal energy, for whom the experience of trance possession acts as a reconfirmation of the bond between humans and deities.

At the end of the ritual, the devotees were awoken and asked to pluck and eviscerate the birds. The preparation, plucking and evisceration of the animals are considered an unpleasant activity by most Candomblé practitioners. During these activities, the social actors engage in conversations that often revolve around its distastefulness . As the sacred mother sums up, "In my house I do not even eat chicken, but here... here we do things that we would never do in our lives!". In these situations, Candomblé practitioners also share the most effective techniques to pluck and cut, but also talk about their memories or experiences of interacting with animals in a rural context. The initial feeling of unpleasantness is then replaced by the acknowledgement that domestic production and

\footnotetext{
${ }^{16}$ Male initiate who does not enter trance and who performs special duties, like slaughtering the animals or playing the drums during celebrations.
} 
consumption of meat was a common practice until the Post-World War II economic transition in Italy. Historical sources argue that in the middle of the twentieth century, rural areas of the country maintained some characteristics of the peasant society: a low-scale production model, family-centered farms and pockets of self-consumption in the Southern part of the country and the Po Valley region (D'ATTORRE; DE BERNARDI, 1994). During the ritual practice of separating the axé, it is common for the Italian devotees to mention their family memories in which poultry meat was produced and consumed within the domestic walls and sometimes share traditional recipes which employ bird parts that would be nowadays discarded ${ }^{17}$. Once the different bird parts are separated, they are given to the sacred mother who cooks them with onion, palm or olive oil, sometimes salt and dried shrimps.

In his famous culinary manual published in 1891 (Science in the Kitchen and the Art of Eating Well) — one of the first cookbooks presenting a comprehensive description of Italian gastronomic culture - Pellegrino Artusi mentions a recipe entirely prepared with chicken giblets.

When you add the necks, heads, and feet to chicken giblets, they become the homely dish that everyone is familiar with. But when you want to make it more refined, using only the livers, combs, unlaid eggs, testicles and gizzards scalded in broth and without the gristle, you can make it more flavorful and delicate by preparing it in the following way. (ARTUSI, 2004, p. 264)

This piece of historical gastronomy shows how notions of taste, edibility, and familiarity are contextual. By remembering flavors and dynamics of production and consumption of an (often imaginary) rural past, Italian followers of Candomblé reinterpret the ritual activity (which is considered unpleasant and exotic) into a more comfortable and familiar sphere of meaning. One Italian practitioner once admitted to me that the smell of palm oil was for her "the smell of Candomblé". The sensorial dimension is one of the first aspects marking the ritual experience. Sutton (2001) argues

\footnotetext{
${ }_{17}$ Interestingly, one well-known Piedmontese recipe is a "risotto" prepared with cockrels' crests.
} 
that the syntesthetic properties of food, evoking colours, shapes, smells, temperatures and involving several senses at once, have a non-verbalized power easy to internalize. Codified ways to cook, prepare or serve food are ritualized actions embedded in everyday life. This sensorial process of crossing traditional memories and creating new landscapes of familiarity helps Italian Candomblé practitioners to interiorize and learn new skills while preparing food offerings.

In the Brazilian case study, the development of the rituals are very similar to those witnessed in Pai Mauro's Candomblé house, but both the social organization and ecological aspects differ greatly. For example, most of the ingredients used in the offerings can be bought in the local supermarket of São Lourenço, and the expensive banana leaves that Italian Candomblé practitioners store in the freezer can be harvested fresh and for free in the forest. Moreover, as Pai Odés terreiro is in a remote area, most rituals can be held at night without fear of disturbing neighbors. In this occasion, ceremonies started at 2.am, and among the sacrificed animals I counted some chickens, goats, guineafowls, doves and one igbin -Yoruba name for the giant African land snail, a large gastropod mollusk used in some culinary preparations in West Africa, while sold solely for ritual purposes in South America, sacrificed to Oxalá. Because of the unavailability of this species, which is also considered very invasive for the ecosystem, the Italian Candomblé house employs common land snails collected in the garden. In both contexts, snails differ from chickens and goats as they are not considered edible by the devotees. Therefore, they are prepared for the orixás but not shared within the community.

The internal division of labor highlights privileges and responsibilities. The kitchen and the orixás' rooms, the domains of secret knowledge and manipulation of axé, are mostly reserved for elders, while juniors are expected to perform more humble tasks, such as keeping the space in order, washing dishes and plucking and eviscerating the animals. As in the Italian context, this procedure is not considered pleasurable. However, while in the Italian Candomblé house this action is performed by most sacred sons and daughters regardless of their hierarchical position (especially because of the low number of participants 
in general), in the Brazilian house this type of work is a social marker within the internal structure of the sacred family. As a junior member complained to me while plucking a chicken, "This is the life of a yawó, you wash the dishes, you clean the animals..." Remembering a situation in which a great number of animals had been sacrificed, a woman with a high hierarchical position said: "There was so much to do that even I had to pluck chickens"18.

Hierarchy also manifests itself in the order in which people serve themselves at the table. When Pai Odé arrives, he sits at the head of the table, and his closest egbomis (elders) sit together with him. When all the elders have served themselves, yawós take what is left and eat with their hands, sitting on the floor. Conversely, in the Italian case it is the sacred father who usually plans and prepares the menu, because of both a personal attitude of Pai Mauro, who is a passionate amateur cook, and a way to control and avoid food waste since Candomblé celebrations take place a few times per year and the house remains empty the rest of the time.

\section{AJEUM: RITUAL DUTIES, CONSUMPTION CHOICES}

As described, some parts of the sacrificial animals were cooked to be offered to the orixás. At this stage, the ritual food is called axé, filled with sacred energy, and devotees are encouraged to eat it. The axé must be consumed in a specific way. It must be distributed on a metal plate and eaten with one's hands while sitting on a straw mat. However, these food items do not always correspond to the tastes of Italian devotees. Offerings are often composed of beans or tubers fried in palm oil or olive oil, saltless porridge or chicken giblets that are not normally part of the Italian diet.

The rest of the meat is cut and stored in a large freezer and cooked in a variety of fashions that best respond to the tastes and culinary habits of the participants (for example the chicken can be roasted or used to make a chicken salad or a curry). Chicken meat is also used to feed the devotees undergoing the rite of passage, who are subjected to a specific diet. During their seclusion period,

18 "Tinha tanto para fazer que até eu limpei galinhas". 
they are fed only chicken or fish pirão (a stew thickened with manioc flour), certain types of tubers, and fruit.

As a vegetarian, Carla often complains about having to eat meat at the terreiro. However, since the meat belongs to sacrificial animals, she cannot object, as the food is supposed to have acquired beneficial properties in the process. Sabrina, a Portuguese woman in her thirties, became a vegan soon after being initiated into Candomblé. As with Carla, the terreiro is the only place where she eats meat. As she explained to me once, "I look at the food, and I thank the chicken that died for me". Vegetarianism and awareness of meat consumption are growing trends in Europe (BAHIA, 2020). These dietary choices often represent a critique of the modalities of meat production from different points of view (environmentalist, ethical, political, etc.), but they are also part of a lifestyle focused on health and body purity (KLEIN, 2008, p. 200-203). While cross-cultural references suggest different influences (Buddhism but also Western political context) in arguments for a meatless diet, it is interesting how vegetarians interpret the consumption of meat coming from sacrificial animals in Candomblé. In these cases, the meat of sacrificial birds not only changes its properties (as it is filled with axé) but somehow maintains the individuality of the being that has been offered. This interpretation lacks more consistent ethnographic data but helps to explain how ritual slaughtering escapes the logic of average food consumption and production. However, recent studies show how abolishing ritual slaughter and meat consumption in terreiros could become one of the next significant trends and transformation in Brazilian Candomblé. Patrício Carneiro Araújo (2019) explains Mãe Solange Buonocore’s motivations, a sacred mother who decided to abolish ritual sacrifice, following complex theological reasons. Since then, Mãe Solange received the visit of many Candomblé practitioners not at ease with animal sacrifice and who were looking for a new way to practice the religion.

One practitioner that approached Mãe Solange is an Italian initiate who started his religious journey in Pai Mauro's terreiro ${ }^{19}$.

\footnotetext{
19 Personal communication with Mãe Solange and the Italian initiate, July and December 2019.
} 
Back in Arborio, Marica and Carla remain in ritual seclusion until the day of the public celebration, which is called candomble and names the religious practice. During the morning, the elders clean the igbás, and the main room is adorned with golden and silver ribbons. At around 3 p.m. guests start gathering in the barracão waiting for the ceremony to start. In the Italian terreiro guests attending the public celebrations number between thirty to fifty people, of whom half are Brazilians who live and work in Italy, and the other half Italian sympathizers and often clients of Pai Mauro or Pai Odé.

Practitioners dress up with finely laced clothes, starched skirts and voluminous turbans. When guests arrive and take a seat in the main room of the terreiro, devotees start dancing in circle and chanting to the sound of drums. Drum-players must be men, and it is common to invite Brazilian musicians to play at the terreiro, since learning the intricate rhythmical patterns of Candomblé is a challenging task for Italian devotees.

When the celebration is over, guests are served a meal that often includes the meat of the sacrificed chickens, in a moment of conviviality called ajeum (literally "meal", which is also the word devotees pronounce before eating). The collective meal in Arborio lets different tastes emerge and mix in an interesting way. Pai Mauro cooks the ajeum trying to take advantage of the chicken meat and please his guests, considering both Italian and Brazilian tastes. At the same time, some of the regular guests also contribute to the meal. Brazilian sympathizers bring homemade empadas (savory pastries filled with meat, fish or palm hearts), cakes or sweets, while Italian attendants bring cakes and regional specialties. This modality of collective food sharing is possible given the low number of devotees and guests who attend the celebrations.

Conversely, in Brazil, is the hosting Candomblé house that usually provides food for everyone, and guests are much more numerous. At the end of the candomblé, a meal consisting of a chicken stew, beans, rice and vegetables is served to participants and guests. In one interview, Pai Odé recalls an ancient tradition called mesa fria ("cold table"), in which the offerings were shared with guests and sympathizers after the public celebration. Nowadays, Candomblé terreiros in some occasions distribute some of the axé to outsiders who come 
to attend the public ceremonies ${ }^{20}$ but mostly tend to prepare more refined and appealing meals, like feijoadas or meat stews with rice and vegetables. In both cases, the sacred fathers try to anticipate the type of meal and taste more palatable to their guests. This process involves considering national preferences and habits. For example, the dark meat of guineafowls is considered a delicacy in Italy, while less common in Brazil. Goat meat has a strong flavor generally not appetizing for people coming from urban and industrialized areas, while being common in the North-East of Brazil and rural areas.

\section{CONCLUSION}

In this paper, I considered food and ritual practices in two different settings. One of the most relevant differences between the two case studies concerns the number of practitioners in the rituals, availability of ingredients, ways of provisioning, organization of the sacred space, perception of hierarchy and division of labor in the two Candomble terreiros. Moreover, cultural perceptions of what is palatable, tasty and edible shape the ways in which food offerings are prepared and shared within the community. Chickens are considered the favorite food and energy source for both deities and humans on a practical and symbolic level, while other animals and birds are regarded as more or less suitable for human consumption depending on the individual or collective tastes. Other animals, such as the igbin, are offered to the orixás but not included in the Candomblé practitioners' diet, neither in Brazil nor in Italy.

Moreover, while it is commonly argued, even by practitioners themselves, that the orixás eat all the bird parts not eaten by humans, the practice of cooking and eating chicken feet, heads and giblets is embedded in the personal memories of Italian practitioners. Italian followers tend to reinterpret the ritual practice by remembering an imagined rural past, creating a new sensorial familiarity with cooking practices and techniques that would be otherwise

${ }^{20}$ During my fieldwork, only the Axéloyá of Salvador da Bahia served the food of the offerings to external guests. 
considered exotic. The rural model of domestic consumption creates an imaginary that allows members to learn new skills and become familiar with new ingredients, like palm oil or manioc flour. Conversely, for Brazilian Candomblé practitioners, the preparation of the sacrificial offerings and its unpleasant materiality is an indicator of a precise status of juniority, in a setting in which internal social structure follows rigid rules and food is distributed giving precedence to elders.

However, while different memories and social structures mediate food practices and innovations in Italy and Brazil, ritual transformations and perceptions do not start solely in the transnational context. The expansion of Afro-Brazilian religions often begins 'at home. Candomblé manifests in its original context an inclusive sensitivity, which makes it possible to offer bread to Italian or French ancestors, to adopt a vegetarian religious practice or to serve festive cakes during public ceremonies, representing the plasticity and openness of Afro-Brazilian religions. The many adaptations here described, in Italy as in Brazil, are to be considered possible reinterpretations of the ritual "recipes" that allowed Candomblé to multiply its sphere of influence beyond Brazilian national borders.

\section{BIBLIOGRAPHY}

1. ARAÚJO, Patrício Carneiro. Candomblé sem Sangue? Pensamento ecológico contemporâneo e transformações rituais nas religiões afro-brasileiras. Curitiba: Appris, 2019.

2. ARAÚJO, Patrício Carneiro. A mesa dos babalorixás: o comer e o poder nos terreiros de candomblé. Itanhaém: Arché, 2020. No prelo.

3. ARTUSI, Pellegrino. Science in the kitchen and the art of eating well. Toronto: University of Toronto Press, 2004.

4. AWOLALU, Joseph Omosade. Yoruba Sacrificial Practice. Journal of Religion in Africa, Leiden, v. 5, n. 2, p. 81-93, 1973.

5. BAHIA, Joana. Different ways of practicing Afro-Brazilian religions in a transnational context: Germany. Studia Religiologica, Cracóvia, v. 51 n. 3, p. 149-163, 2018. 
6. BAHIA, Joana; DANTAS Caroline Moreira Vieira. Música, corporalidade e recriação diaspórica no candomblé na Alemanha. Ciencias Sociales y Religión, Porto Alegre, v. 28, p. 82-98, 2018.

7. BAHIA, Joana. Europa underground. Enverdecimento do ser, Reforma da Vida, bruxarias e outros modos de pensar o espiritual. Antropolítica, Niterói, n. 48, 2020.

8. BASTOS, Cristiana, Omulu em Lisboa: etnografias para uma teoria da globalização. Etnográfica, Lisboa, v. 5, n. 2, p. 303-324, 2001.

9. CAPPONI, Giovanna. The Garden and the market: human-environment relations and collective imaginary in afro-brazilian candomblé between Italy and Brazil. Studia Religiologica, Cracóvia, v. 51, n. 3, p. 165-178, 2018.

10. D'ATTORRE, Pier Paolo; DE BERNARDI, Alberto. Il 'lungo addio': una proposta interpretativa, In: D'ATTORRE, Pier Paolo; DE BERNARDI, Alberto. Studi sull'agricoltura italiana: società rurale e modernizzazione. Milano: Feltrinelli, 1994. p. xi-lvi.

11. FIRTH, Raymond. Offering and sacrifice: problems of organization. Journal of the Royal Anthropological Institute of Great Britain and Ireland, London, v. 93 n. 1, p. 12-24, 1963.

12. GOLFETTO, Tatiana. Candomblé Ketu in Italy: dialogues and adaptations. Studia Religiologica, Cracóvia, v. 51 n. 4, p. 265-278, 2018.

13. GEURTS, Kathryn Linn. Culture and the senses: bodily ways of knowing in an African Community. Oakland: University of California Press, 2018.

14. GUILLOT, Maia. "Axé Ilê Portugal": parcours migratoires et religions afro-bBraziliennes au Portugal. Autrepart, Paris, v. 56, n. 4, p. 57-74, 2010.

15. GUILLOT, Maia; HUET, Nahayeilli Juárez. Dinámicas Religiosas y Lógica Mercantil de las Religiones Afroamericanas en México y Portugal, In: ARGYRIADIS, Kali; CAPONE, Stefania; DE LA TORRE, Renée; MARY, André (org.). En Sentido contrario: transnacionalización de religiones africanas y latinoamericanas. Cidade do México, DF: IRD Éditions, 2012. p. 63-84.

16. HALLOY, Arnaud. Um candomblé na Bélgica: traços etnográficos de uma tentativa de instalação e suas dificuldades. Revista de Antropologia, São Paulo, v. 47 n. 2, p. 453-493, 2004.

17. JOHNSON, Paul Christopher. Secrets, gossips, and gods: the transformation of brazilian candomblé. Oxford: Oxford University Press, 2002.

18. KLEIN, Jakob. Afterword: comparing vegetarianisms. South Asia, Oxfordshire, v. 31, n. 1, p. 199-212, 2008.

19. LEWIS, Gilbert. Day of Shining Red. Cambridge: Cambridge University Press, 1980. 
20. LINN GEURTS, Kathryn. Culture and the senses: bodily ways of knowing in an African community. Berkeley: University of California Press, 2002.

21. LOPES, Nei. African religions in Brazil, negotiation and resistance: a look from within. Journal of Black Studies, Thousand Oaks, v. 34, n. 6, p. 838-860, 2004.

22. REINHARDT, Bruno. Intangible heritage, tangible controversies: the baiana and the acarajé as boundary object in contemporary Brazil. In: MEYER, Brigit; VAN DE PORT, Mattijs (org.). Sense and essence: heritage and the cultural production of the real. New York: Berghan Books, 2018. p. 75-108.

23. SARAIVA, Clara. Afro-brazilian religions in Portugal: bruxos, priests and pais de santo. Etnográfica, Lisboa, v. 14, n. 2, p. 265-288, 2010.

24. SARAIVA, Clara. Blood, sacrifices and religious freedom: afro-brazilian associations in Portugal. In: BLANES, Ruy; MAPRIL, José (org.). Site and politics of religious diversity in Southern Europe: the best of all gods. Leiden: Brill, 2013. p. 129-154.

25. SUTTON, David. Remembrance of repasts: an anthropology of food and memory. London: Berg, 2001

26. SUTTON, David. Cooking Skills, the senses, and memory: the fate of practical knowledge. In: COUNIHAN, Carole; VAN ESTERIK, Penny (org.). Food and culture: a reader. 3. ed. London: Routledge, 2013. p. 299-319.

27. TEISENHOFFER, Viola. Umbanda, New Age et psychothérapie. Aspects de l'implantation de l'umbanda à Paris. Ateliers du LESC, Nanterre, v. 31, 2007. Disponível em: http://bit.ly/2T2FMZg. Acesso em: 8 dez. 2018.

28. VOGEL, Arno; MELLO, Marco Antonio da Silva; BARROS, José Flávio Pessoa de. A galinha-d'angola: iniciação e identidade na cultura afro-brasileira. Rio de Janeiro: Pallas, 1993.

29. WILLERSLEV, Rane. Not animal, not not-animal: hunting, imitation and empathetic knowledge among the siberian Yukaghirs. Journal of the Royal Anthropological Institute, London, v. 10, n. 3, p. 629-652, 2004. 